Discussion

Papers

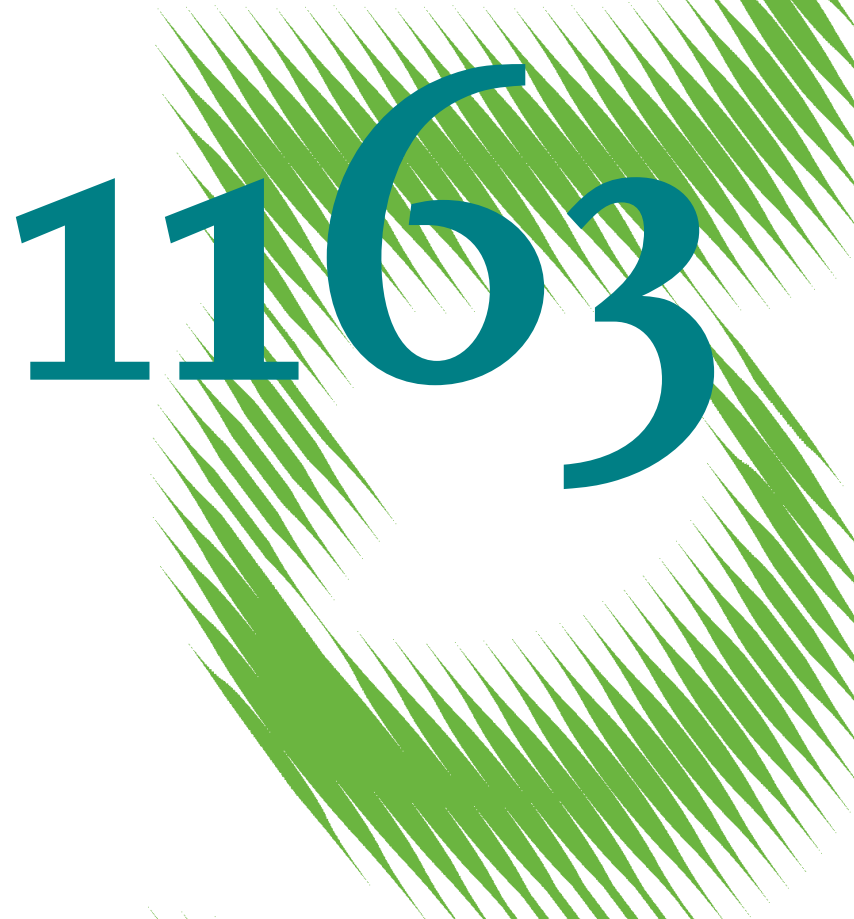

Determinants of Trade with Solar Energy Technology Components

Evidence on the Porter Hypothesis? 
Opinions expressed in this paper are those of the author(s) and do not necessarily reflect views of the institute.

IMPRESSUM

(C) DIW Berlin, 2011

DIW Berlin

German Institute for Economic Research

Mohrenstr. 58

10117 Berlin

Tel. $+49(30) 89789-0$

Fax +49 (30) $89789-200$

http://www.diw.de

ISSN print edition $1433-0210$

ISSN electronic edition 1619-4535

Papers can be downloaded free of charge from the DIW Berlin website:

http://www.diw.de/discussionpapers

Discussion Papers of DIW Berlin are indexed in RePEc and SSRN:

http://ideas.repec.org/s/diw/diwwpp.html

http://www.ssrn.com/link/DIW-Berlin-German-Inst-Econ-Res.html 


\title{
Determinants of Trade with Solar Energy Technology Components Evidence on the Porter Hypothesis?
}

\author{
Felix Groba \\ (DIW Berlin)
}

\begin{abstract}
Studies analyzing renewable energy market development usually investigate additional capacity or investment. Characteristics, roles and determinants of cross border trade with renewable energy system components remain blurred. Environmental regulation and renewable energy policies are important in promoting renewable energy use. Yet, the effect of respective policies on determining exports remains ambiguous. The Porter hypothesis and the lead market literature argue that environmental regulation leads to a comparative export advantage. Empirical studies testing both hypotheses reach diverging conclusions and rarely focus on the renewable energy sector. Using solar energy technology components, this study adds to the literature by explaining exports of environmental technologies. The analysis uses a gravity trade model and a unique panel dataset to test the role of renewable energy policies on environmental technology exports from OECD countries and to describe structure and development of international solar energy technology component trade. The results find a rapidly growing market with trade dominated by European countries. The study supports the Porter and the lead market hypotheses as early adopters of strong renewable energy policies have gained a comparative advantage. Analyzing the importer side, the study suggests that regulatory policies and import tariffs determine export flows of solar energy technology components.
\end{abstract}

Keywords: Solar Energy Technologies, Energy Policy, Environmental Regulation and Trade, Trade Barriers

JEL Classification: F14, F18, Q42, Q55, Q56 



\section{Introduction}

Clean energy technologies play an important role in the nexus between economic development and sustainable energy system transformation. Consequently, the diffusion and transfer of climate friendly energy technologies are decisive topics in international climate negotiations (UNFCCC, 2007, 2009). The current and expected development of the global renewable energy market is monitored in numerous studies (EREC and Greenpeace, 2007; IEA, 2009, 2010b). In this context, solar energy is identified as a crucial piece of the future energy mix, with, consequently, large growth potential for solar energy technologies. However, these studies either investigate added capacity or investments into renewable energy projects in order to describe growth, structure and development of an increasingly dynamic market (REN21, 2009; UNCTAD, 2010; UNEP, 2010). The role of the cross border trade of technology components in this context is largely neglected by academia and policy even though international trade in general is identified as a decisive channel for technological change (Grossman and Helpman, 1990; Vollebergh and Kemfert, 2005; Young, 1991).

Data on cross border trade of solar energy technology components (SETC), required to setup solar energy systems, indicate a fast growing international market with larger growth rates than total trade. Between 1996 and 2008, exports of these clean technology goods increased by 600 percent from US\$ 15.8 billion to US\$ 95.2 billion. ${ }^{1}$ Analyzing the data unveils a market dominated by OECD countries that account for approximately 90 percent of these exports in 1996 and, still, 60 percent in 2008 (Figure 1, Figure 2). Hence, these figures also outline the growing importance of emerging economies.

\footnotetext{
${ }^{1}$ Trade data is obtained from UNCTAD COMTRADE database based on the Harmonized Systems codes. For more detailed data specification see Section 4.1 and Appendix 2.
} 
Figure 1: Development of solar energy technology component exports to the world by country group 1996-2008.

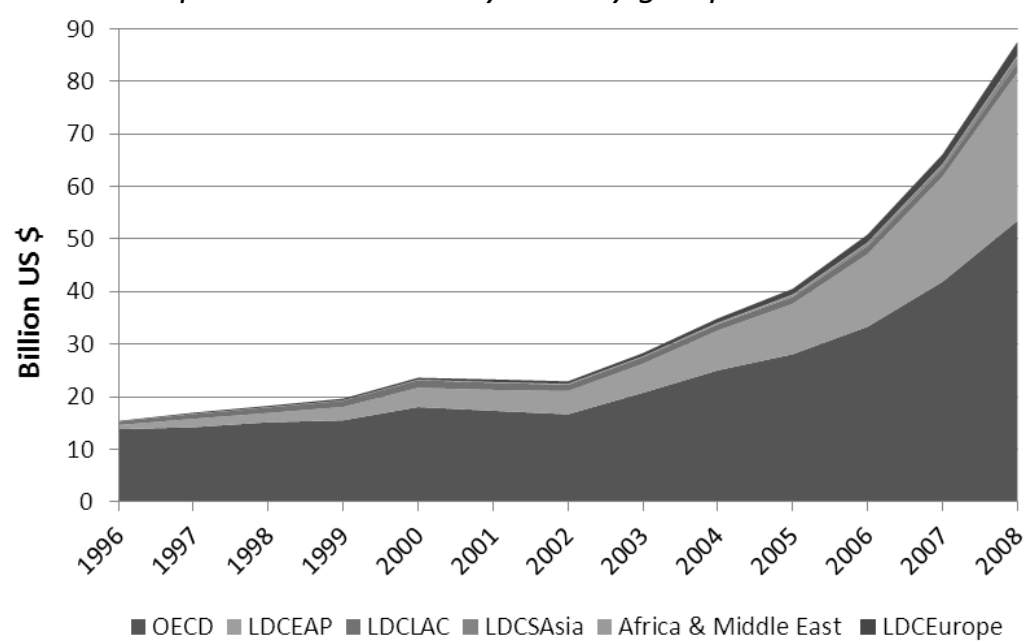

Source: UNCTAD COMTRADE database 2011.

Figure 2: Export flow of solar energy technology components 2008 by region in billion US $\$$.

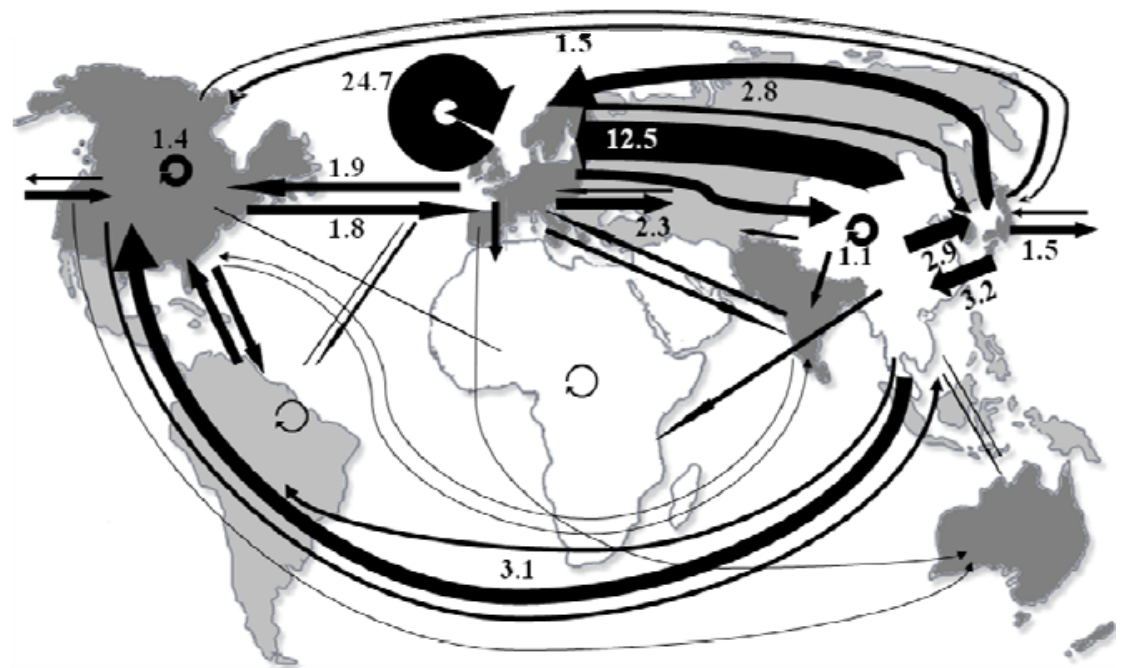

Source: own illustration based on UNCTAD COMTRADE data 2011.

An analysis of the trade between world regions shows that main import markets are high income OECD countries, with most trade occurring between OECD countries. While trade between developing countries remains minor, some developing countries, such as China, 
India and Brazil, export substantial SETCs to developed countries. The data show that 15 countries accounted for 86 percent of SETC-exports in both 1996 and 2008. In 1996 the market share of OECD countries was 83 percent; in 2008 these countries accounted for 60 percent of exports. The analysis of country specific export flows and market shares reveals dynamic market growth and the dominance of only some countries (Appendix 1).

The main question is why have some countries developed an export advantage in SETC trade? Another central question is why trade in SETC between developed and developing countries remains limited. Therefore, the motivation of this study is to determine export drivers of SETCS and to explain differences between countries in exporting and importing these technologies. The results are interesting from an economic as well as from a policy perspective. Identifying instruments promoting trade with clean energy technologies could be an element to be considered in the debate on sustainable growth in the OECD and European Union. Furthermore, as the transfer of clean energy technologies remains an important issue in global climate negotiations, recognizing obstacles to trade with clean energy technology could identify future areas of cooperation among developed and developing countries.

The academic literature evaluates whether or not the introduction of environmental regulation increases the use and availability of environmental technologies (Dechezleprêtre et al., 2011; Jaffe et al., 2002; Jaffe and Stavins, 1995). Yet, literature addressing the question of which policy instruments foster the international diffusion of environmental technologies via trade remains limited. In this context, empirical studies of the different versions of the Porter hypothesis are of interest. The Porter hypothesis argues that environmental regulation positively affects innovation and comparative advantage in the 
world market (Porter and van der Linde, 1995). However, with the exception of Constantini and Crespi (2008) studies of trade in specific renewable energy technologies and the effect of regulatory policies on trade are rare.

Focusing the analysis to exports of SETC from OECD countries to the world using a uniquely constructed dataset, this paper closes the gap and contributes to the literature by testing two hypotheses:

(1) Based on the Porter hypothesis, countries with a strong renewable energy policy have an export advantage in the global market versus countries with weak or nonexistent policies.

(2) Receiving countries with a regulatory framework supporting renewable energies and with low trade barriers will have more clean technology imports than countries without supportive frameworks and with higher trade barriers.

Using a gravity model of trade, the study is conducted using a Poisson Pseudo Maximum Likelihood (PPML) estimator, as proposed by Santos Silva and Tenreyo (2006). This approach uses the full information given by the panel data structure, in contrast to ordinary least squares estimation applied in earlier trade research, as both zero trade flows and heteroscedasticity are taken into account.

The remainder of this paper is structured as follows. Section 2 integrates this paper into the current academic and empirical literature on environmental regulation, innovation and trade. Section 3 describes the empirical model and estimation method. Data and descriptive statistics are outlined in Section 4. Section 5 presents and discusses estimation results. Section 6 concludes. 


\section{Regulation, innovation and trade - a literature overview}

The interaction between trade flows and environmental regulation has become prominent in research since the late 1970s. Focusing on energy intensive industries, the driving question was whether environmental regulation reduces or increases a country's competitiveness (Galeotti and Kemfert, 2004). The pollution haven and the Porter hypothesis are widely discussed ideas in this respect.

According to the pollution haven hypothesis, countries with relatively strict environmental standards experience decreasing exports as industries that face greater regulatory standards and thus higher production costs shift production to countries with relatively loose environmental regulation or become less competitive and lose market share (Copeland, 2003).

The rather static view of the pollution haven hypothesis is challenged by earlier work of Porter and van der Linde (1995) on basis of a dynamic competitiveness approach. The strong version of the Porter hypothesis argues that environmental regulation induces costsaving innovations that compensate compliance costs and thus positively affects the dynamic behavior of an economy. Jaffe et. al (1995) offers two other variants of the hypothesis: a weaker and more narrow interpretation. The weaker version of the Porter hypothesis argues that environmental regulation will only stimulate certain innovations leaving ambiguous effects on comparative advantages and society. ${ }^{2}$ Following these versions of the Porter hypothesis, the empirical literature can be differentiated into two branches.

\footnotetext{
${ }^{2}$ The narrow interpretation of the Porter hypothesis, offered by Jaffe et. al (1995), which asserts that flexible, market oriented, environmental policy instruments give greater incentives to innovate than prescriptive regulations, is not relevant in this particular study and is omitted from further discussion.
} 
The first, analyzing either the pollution haven or the strong version of the Porter hypotheses, estimates the impact of environmental regulation on industry and country performance measures such as firm productivity or total trade volumes. Studies in this context have ambiguous results with respect to both hypotheses. Therefore, there is no clear empirical evidence of whether regulatory costs for firms are too high to negatively affect competitiveness. Neither is it clear whether environmental regulation induces innovation that compensates for the cost of regulatory compliance (Antweiler et al., 2001; Grether and de Melo, 2003; Harris et al., 2002; Jug and Mirza, 2005).

The second branch, empirical studies testing the weak version of the Porter hypothesis, estimates regulatory impacts on innovation measured by patent applications, R\&D investment and capital investments in new technologies. Jaffe and Palmer (1997) suggest a weak, but positive, link between pollution abatement costs as a proxy for environmental regulation strictness and total R\&D expenditure for the U.S. manufacturing industry. While they do not establish a significant relationship between regulation and patent application, Popp (2006), focusing on the U.S., and DeVries and Withagen (2005), focusing on OECD countries, provide evidence that the number of relevant patents increased shortly after the introduction of sulfur and nitrogen dioxide regulation.

Studies testing the weak version of the hypothesis are starting to focus on the impact of regulation on the renewable energy sector. Johnston et al. (2010) find that public policies play a significant role in determining patent applications. By differentiating policy types, they show that broad based policies, such as tradable energy certificates, are more likely to exhibit an innovation effect on technologies close to competitiveness while targeted policies, 
such as feed-in tariffs, induce innovation in costly technologies such as solar energy technologies.

As most studies focusing on renewable energy analyze the impact of regulation on innovation and knowledge spillovers, there remains a research gap with respect to the determinants of cross border trade in renewable energy technologies and the role of policy in that context. In general, it is recognized that technology policies, specifically research and development budgets, directly affect exports and may also produce spillover effects (Krugman, 1979; Wang et al., 2010). In theory, R\&D or knowledge accumulation should positively affect bilateral trade between countries (Grossman and Helpman, 1993). Empirical research by Levinson (2009), analyzing the U.S. manufacturing sector, finds that a mix of innovation and environmental policy may lead to increased environmental efficiency in trade. In order to establish a link between policy induced innovation and trade, literature on lead markets is of interest. It augments the weaker interpretation of the Porter hypothesis by suggesting that, among other factors, an early introduction of adequate technology support policies can create an industry with a competitive world market advantage (Beise, 2004; Beise and Rennings, 2005).

To our knowledge, Constantini and Crespi (2008) provide the only empirical study focusing on the role of policy in determining trade of renewable energy technologies. Using general proxies for environmental regulation strictness, they provide affirmative evidence on the weak interpretation of the Porter hypothesis. Yet, their general analysis neither controls for technology specific characteristics in trade and policy design nor for the role of policy duration. Furthermore, the role of trade barriers, as well as the policy and market environment in importing countries receives only little attention. 


\section{Estimation method of trade analysis}

Empirical studies in international trade typically adopt the gravity model in order to estimate the relationship of various policies, including preferential trade agreements, environmental regulation and innovation, on international trade flows with respect to various goods and sectors. Introduced by Tinbergen (1962) and extended with various additional variables to analyze the role of border effects, trade and economic policy and relative factor endowment, the model is the workhorse of trade analysis. The popularity of the model can be explained by its successful empirical performance and by its significantly strengthened theoretical foundations (Anderson and van Wincoop, 2003; Anderson, 1979; Bergstrand, 1985; 1989; Feenstra et al., 2001; Jug and Mirza, 2005).

The general stochastic formulation of the gravity model (1) describes trade flows $(X)$ from exporting country $i$ to destination country $j$ at time $t$ as a function proportional to economic masses $(Y)$ and inversely proportional to their distances $(D)$ :

(1)

$$
X_{i j t}=\beta_{0}\left(Y_{i t}^{\beta_{1}} Y_{j t}^{\beta_{2}} / D_{i j}^{\beta_{3}}\right) \eta_{i j t} .
$$

The parameters $\beta_{0}, \beta_{1}, \beta_{2}, \beta_{3}$ are unknown and the error term $\left(\eta_{i j t}\right)$ is assumed to be independent of the regressors. Recent trade studies apply the gravity model to panel data as it allows the recognition of the development of variables over time. Furthermore, the panel context allows for controlling the heterogeneity among countries and temporal effects by means of country and year fixed effects. In this context, the role of bilateral trade costs is addressed repeatedly (Anderson and van Wincoop, 2003; McCallum, 1995). Anderson and van Wincoop (2003) argue that three factors of bilateral trade costs need to be accounted for in order to reduce heterogeneity and to correctly estimate a theoretically based gravity 
model: bilateral trade barriers between countries $i$ and $j$, general trade resistance of $i$, and $j$ 's resistance to trade with others. Consequently, they argue in favor of enlisting a proxy for the barriers of trade that a country faces with all its trading partners by including a multilateral trade resistance term. Several methods are proposed for empirically implementing this approach. Feenstra (2002) proposes the method that is most commonly used: capturing country specific multilateral trade resistance by including importer $\left(d_{i}\right)$, exporter $\left(d_{j}\right)$ and time dummy $\left(d_{t}\right)$ variables to capture fixed effects in the different dimensions (Egger, 2000; Egger and Pfaffermayr, 2003; Matyas, 1998; Ruiz and Vilarrubia, 2008). Under the assumption of homoscedasticity, applied empirical trade studies transform the model into logs establishing a linear relationship estimated with simple fixed effect ordinary least squares (OLS) that conveniently allows for interpretation in percentage changes. Consequently, the log-linear model reads as follows:

$$
\ln X_{i j t}=\ln \beta_{0}+\beta_{1} \ln Y_{i t}+\beta_{2} \ln Y_{j t}+\beta_{3} \ln D_{i j}+d_{i}+d_{j}+d_{t}+\ln \eta_{i j t}
$$

Analyzing the export dynamics of renewable energy technologies Constantini and Crespi (2008) apply a similar estimation framework. They find that countries with stringent environmental standards and higher innovation capacity export more environmental friendly energy technologies.

However, both the empirical and theoretical literature on the implementation of the gravity model shows several shortcomings in using OLS estimation that affect consistency. The first problem, outlined by Santos Silva and Tenreyro (2006), is that the crucial assumption of homoscedasticity is unrealistic in trade data. Thus, applying traditional estimation techniques in log linearized form renders inconsistent estimates. 
A second problem is the prevalence of zero bilateral trade flows. Most studies using OLS estimation disregard zero trade flows between countries, as in a log-linearized model only positive trade flows are used for estimation. However, zero trade flows are quite common and might not occur randomly but rather as the result of a selection procedure. Thus, dropping zeros from the dataset for OLS estimation results in biased estimates as information on the extensive margin, explaining whether or not countries trade, is excluded (Frankel, 1997; Helpman et al., 2008).

A robust alternative drawing attention in literature is the Poisson pseudo -maximumlikelihood (PPML) estimator, proposed by Santos Silva and Tenreyro (2006). Applied to the gravity model in level-log form it provides consistent parameter estimates, even with heteroscedastic errors and allows the inclusion of zero trade flows between countries into the analysis. The estimation method tests favorably against other estimation methods and is successfully implemented in similar trade studies (Burger et al., 2009; Magee, 2008; Santos Silva and Tenreyo, 2010a, b; Schumacher and Siliverstovs, 2009).

Consequently, this study uses the PPML estimator for two reasons. First, as only a small sector is analyzed, zero trade flows are prevalent, especially during the early years of the analysis. Second, consistent parameter estimates, even with heteroscedastic errors, are obtained; accounting for the fact that homoscedasticity is unlikely. The final formulation of the gravity model, extended by variables controlling for the role of environmental and renewable energy policy, as outlined in section 4, is as follows: 
(5)

$$
\begin{aligned}
\text { SolarEXP }_{\mathrm{ijt}} & =\beta_{0}+\beta_{1} \ln \left(\mathrm{GDP}_{\mathrm{it}}\right)+\beta_{2} \ln \left(\mathrm{GDP}_{\mathrm{jt}}\right)+\beta_{3} \ln \left(\mathrm{POP}_{\mathrm{it}}\right)+\beta_{4} \ln \left(\mathrm{POP}_{\mathrm{jt}}\right) \\
& +\beta_{5} \ln \left(\text { distance }_{\mathrm{ij}}\right)+\beta_{6} \operatorname{language}_{\mathrm{ij}}+\beta_{7} \ln \left(\operatorname{IndexEnvReg}_{\mathrm{it}}\right) \\
& +\beta_{8} \ln \left(\text { SolarElect }_{\mathrm{it}}\right)+\beta_{9} \ln \left(\text { RDsolar }_{\mathrm{it}}\right)+\beta_{10} \text { Policies }_{\mathrm{it}} \\
& +\beta_{11} \ln \left(\operatorname{Import~Tariff~}_{\mathrm{jit}}\right)+\beta_{12} \ln \left(\operatorname{IndexEnvReg}_{\mathrm{jt}}\right)+\beta_{13} \ln \left(\text { ReElect }_{\mathrm{it}}\right) \\
& +\mathrm{d}_{\mathrm{i}}+\mathrm{d}_{\mathrm{j}}+\mathrm{d}_{\mathrm{t}}+\varepsilon_{\mathrm{ijt}}
\end{aligned}
$$

\section{Data}

\subsection{Solar energy technology components in export statistics}

The aim of the study is to determine the drivers of international trade in solar energy technology components. Therefore, the dependent panel variable is the bilateral export flow of SETC (SolarEXP $i j t$ ) from country $i$ to $j$ at time $t$. The empirical analysis is confined to exports from 21 OECD $i$-exporting countries ${ }^{3}$ to $129 j$-importing countries, including all OECD countries. Although Chinese exports have grown strongly since 1996 these are excluded due to the lack of available robust data on control variables. The time period analyzed with the balanced panel is 1999 to 2007, as insufficient data for several control variables is available prior to this period.

SETC are defined in this study as investment goods and associated products required in both solar thermal and solar photovoltaic energy systems. In an effort to identify goods for liberalization in the WTO framework, a classification with respect to environmental and energy technology goods, including renewable energy technology goods, within the Harmonized System (HS) codes is defined (OECD and Eurostat, 1999; UNCTAD, 1995). Consequently, using the technology differentiation by Steenblik (2005a, b, 2006a) and Wind (2008), a product group based on 6-digit HS 1996 codes (Appendix 2) is constructed using

\footnotetext{
${ }^{3}$ Australia, Austria, Belgium, Canada, Denmark, Finland, France, Germany, Greece, Ireland, Italy, Japan, Korea, the Netherlands, Norway, Portugal, Spain, Sweden, Switzerland, the United Kingdom and the United States
} 
the UNCTAD COMTRADE database. This approach of using HS-codes is successfully implemented in other descriptive and empirical studies focusing on climate change mitigation technologies (Costantini and Crespi, 2008; Hamwey, 2005; UNCTAD, 2003).

Although it might be controversial to jointly analyze solar thermal and photovoltaic components (as they are technologically distinct) this is a common approach in the literature on innovation in renewable energy technologies (Johnstone et al., 2010). Furthermore, the sectorial breakdown of related trade analyzes often only distinguishes between research intensiveness of industries. Studies analyzing the carbon content of trade also only refer to dirty and clean industries, while refraining from a detailed technology specific or sectorial breakdown, as conducted in this study on the solar energy industry.

Nevertheless, focusing on solar energy technologies, as a subgroup of energy technologies, requires addressing data validity. One problem is that data might be inflated, as the products' environmental end use cannot be monitored, i.e. goods that are used for renewable energy systems and goods that might be used otherwise are traded under a common HS code and the renewable energy goods share under one HS code might vary between countries. However, the method used constructs the best available proxy for a cross time cross country analysis, as data is based on an international common methodology and product similarity can be assumed making the actual end use irrelevant.

\subsection{General trade estimation parameter}

The general gravity model, as outlined in Section 3, describes trade flows as a function proportional to general variables such as income, population, distance and language. Therefore, exporting and importing countries' GDP $\left(G D P_{i t}, G D P_{j t}\right)$ and populations $\left(P O P_{i t}\right.$ 
$\left.P O P_{j t}\right)$ are included. In theory, the bilateral trade volume is positively related to a country's income, but countries with a larger population are expected to trade less as available resources and the domestic market size are expected to be positively correlated with population size (Frankel, 1997). Furthermore, bilateral distance $\left(D I S T_{i j}\right)$, to control for trade reducing transportation costs, and common language $\left(L A N G_{i j}\right)$, controlling for trade promoting cultural proximity, are included. Data for these variables are retrieved from the World Bank World Development Indicators (2010) and from CEPII's Gravity Dataset (2010).

\subsection{The effect of environmental regulation on exports}

As noted, the empirical literature on the interaction between trade and environmental regulation remains ambiguous regarding support for either the Porter or the pollution haven hypotheses. Yet again, according to the Porter hypothesis, stricter environmental regulation induces innovation that subsequently positively affects an economy's dynamic behavior and its international competitiveness.

Estimating the impact of environmental and renewable energy policy on specific exports with renewable energy technology it is necessary to:

(1) differentiate between input and output oriented measures of environmental stringency as the former are devoted to environmental protection while the latter reflect the results of regulation providing more accurate proxies of environmental policy strictness (van Beers and can den Bergh, 1997); and

(2) differentiate between environmental regulation strictness in general and renewable energy supportiveness as the environmental regulation targets various policy fields but will not necessarily impact the renewable energy sector, which is, 
per se, assumed to be environmentally friendly and rather sensitive to specific sector regulation.

In the literature on environmental regulation and trade an index is commonly used as an output oriented measure for relative environmental strictness. Following the method of van Beers and van den Bergh (1997) and Harris et al. (2002), sample countries are ranked based upon the absolute energy intensity in $t$ and the change in energy intensity since 1990, assigning the lowest rank to the worst performer. The final environmental strictness indicator (IndexEnvReg it $_{\text {) }}$ ranging between 0 (lax regulation) and 1 (strict regulation) is derived by dividing the ranks by the number of exporting countries in the sample. In the given panel structure this index better allows control for the relative political importance of energy saving strategies and investigating its effect on export flows than a comparison of energy use and emissions level, as done by Constantini and Crespi (2008). Data on energy intensity is obtained from the U.S. Energy Information Administration's International Energy Statistics Database (2011) in BTU per 2005 PPP Dollar of GDP.

However, this measure is quite broad and does not focus on renewable energy regulation in particular. Thus, studies using only broad environmental regulation measures for analyzing specific sectors, such as Constantini and Crespi (2008), are likely to not capture the true effect of renewable energy regulation on exports from that specific sector. Consequently, the share of solar electricity generation from total generation (SolarElect ${ }_{i t}$ ) is included (Figure 3) as the sectorial focus is on solar energy technology components (SETC). 
Figure 3: Share of solar electricity generation in total electricity generation for selected OECD countries $1996-2007$.

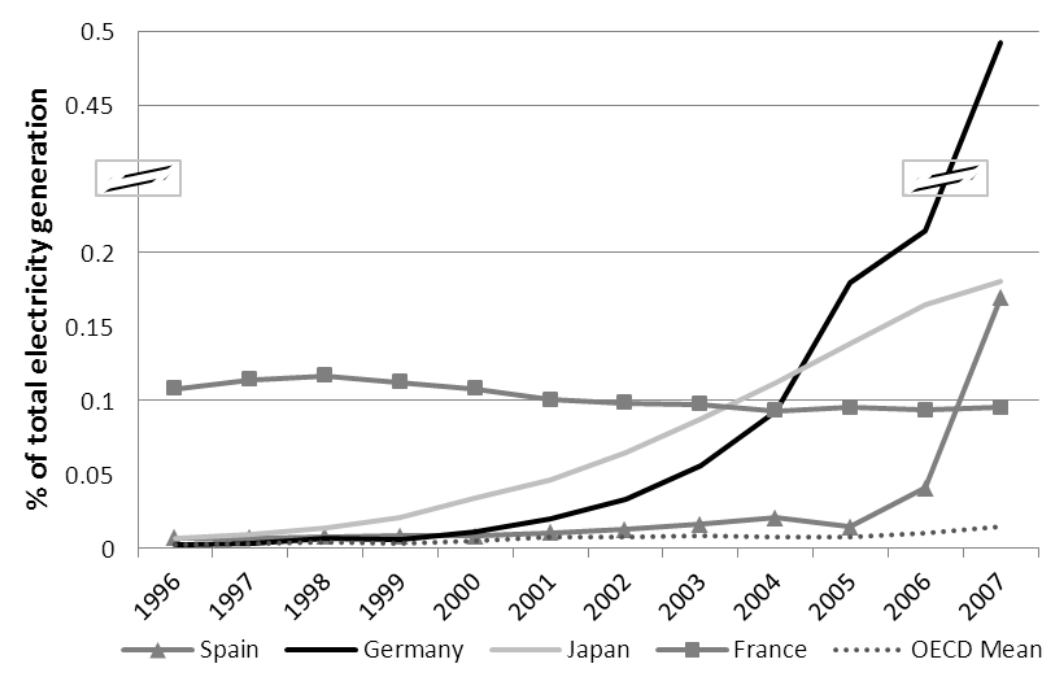

Source: own calculations based on U.S. EIA International Energy Statistics Database (2011).

This output oriented measure is expected to positively affect export flows as it reflects: (1) the results of regulation targeting solar energy supply expansion and thus the regulatory system support for solar energy; and (2) indirectly the strength of a national industry producing the respective technology components. Data for both solar and total net electricity generation are obtained from the U.S. Energy Information Administration's International Energy Statistics Database (2011).

The output oriented measures proxy the result of environmental regulation. Yet, as this study focuses on the effect of regulation on specific renewable technology trade flows, input oriented indicators are tested as well. In OECD countries, the development of renewable energy sources is supported by a variety of policy instruments that may increase the demand for, and supply of, renewable energy technologies. The International Energy Agency (IEA) compiled the report on "Renewable energy market and policy trends," which distinguishes between seven policy types: (1) R\&D support; (2) tariff incentives (e.g. feed-in 
tariffs, guaranteed price and bidding systems); (3) investment incentives (e.g. grants, risk guarantees, low-interest loans); (4) obligations (e.g. portfolio standards, targets and quota systems); (5) tax measures (e.g. accelerated depreciation); (6) tradable certificates; and (7) voluntary programs (IEA, 2004). Although there is research measuring the strength of quota obligations (Yin and Powers, 2010) and feed-in-tariffs (Johnstone et al., 2010), the lack of data and the heterogeneous character of the policies adopted by different countries does not facilitate cross country evaluation of regulatory stringency or renewable energy supportiveness for most of these policies. However, data concerning the public R\&D budget for solar energy (RDSolar $\left.{ }_{i t}\right)$ is available and is included in this study as a continuous variable representing relative policy stringency. Johnstone, Haščič and Popp (2010) argue that countries with a higher public R\&D budget are considered to be more committed to solar energy technology. The overview in Figure 4 outlines the R\&D budget for solar energy difference between selected OECD countries.

Figure 4: Public R\&D expenditure for solar energy in US \$ (2009 US \$ PPP) for selected OECD countries $1996-2007$.

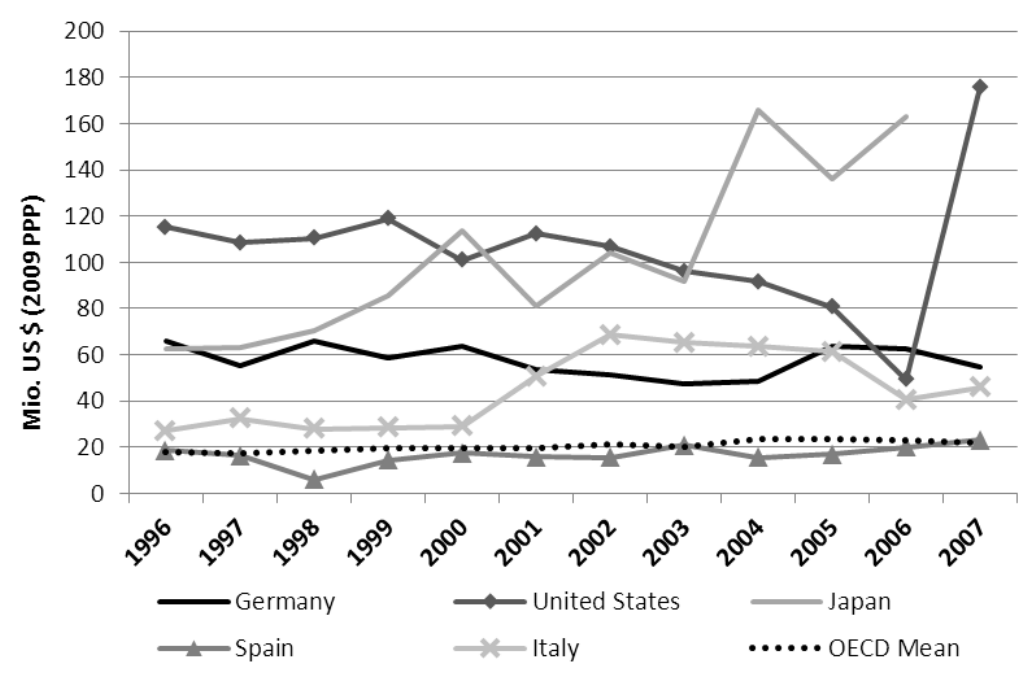

Source: IEA Energy Technology Research and Development Database (2011). 
It indicates that the countries that are the main exporter of solar energy technology are also those with an above OECD average R\&D budget for solar energy. The coefficient is expected to be positive. Public sector R\&D expenditure data for solar energy is taken from the IEA's Energy Technology Research and Development Database (IEA, 2010a).

For the remaining renewable energy policies summarized in the IEA report Table 1 provides a representation of policy introduction in OECD countries for incentive tariff, renewable energy obligation and tradable certificate policies.

Table 1: Years of renewable energy policy enactment in OECD countries.

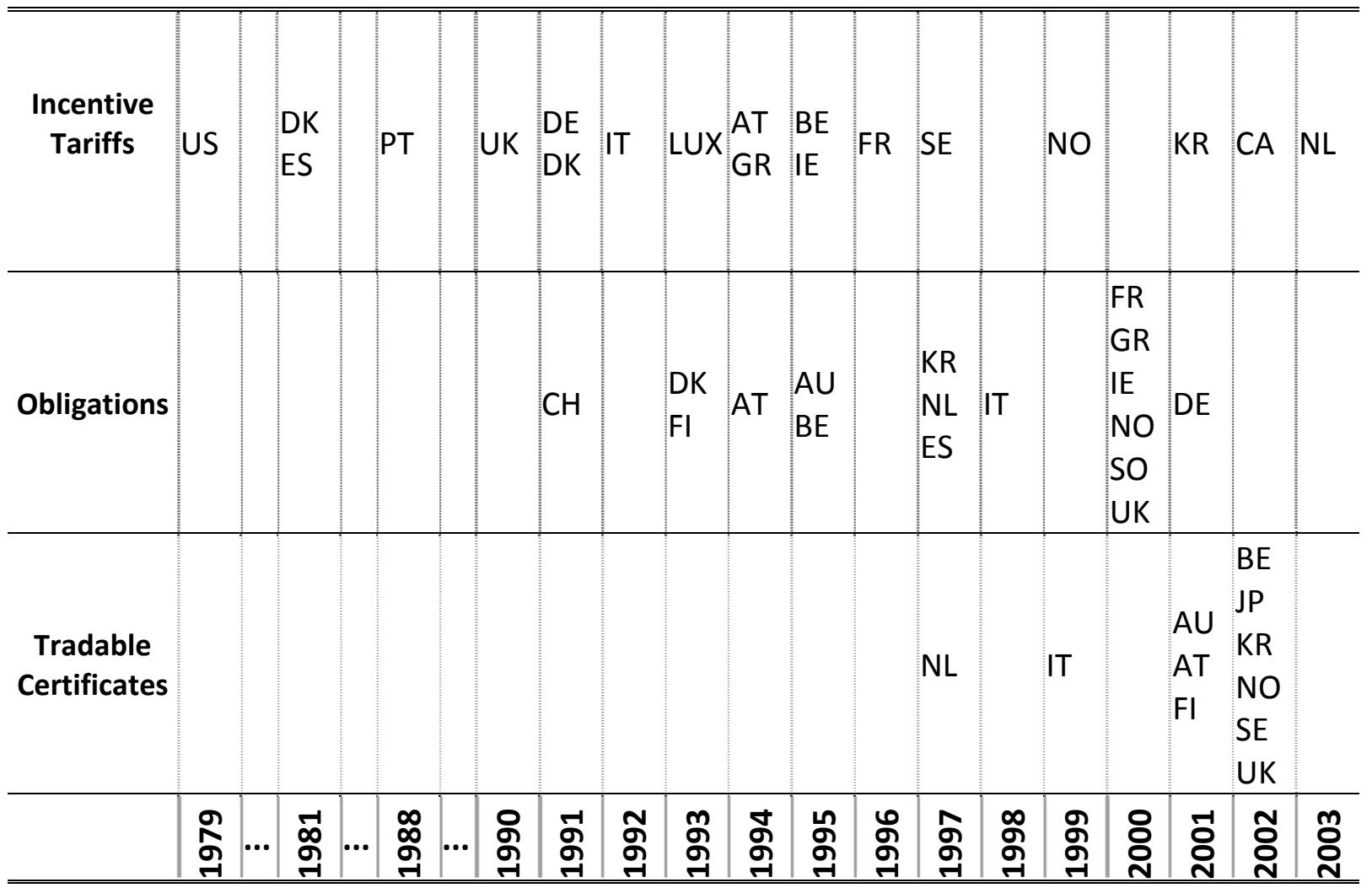

Note: ISO-3166-2 codes representing OECD countries: AT=Austria, AU=Australia, BE=Belgium, $\mathrm{CA}=$ Canada, $\mathrm{CH}=$ Switzerland, $\mathrm{DE}=$ Germany, $\mathrm{DK}=$ Denmark, $\mathrm{ES}=$ Spain, $\mathrm{Fl}=$ Finland, $\mathrm{FR}=$ France, UK=United Kingdom, $G R=$ Greece, IE=Ireland, IT=Italy, JP=Japan, KR=Republic of Korea, NL=Netherlands, NO=Norway, PT=Portugal, SE=Sweden, US=United States, Source: IEA (2004).

For these policies, various binary dummy variables are constructed in order to measure the effect of policies on solar energy technology component exports from OECD countries. In 
general, the introduction of alternative energy policies aims at supporting the development of clean energy technologies in the national market. Yet, this argument can be extended as not only is the expansion of installed capacity supported, but indirectly the development of an adequate industry is also supported. Therefore, the estimation coefficients are expected to be positive.

Considering the arguments of the lead market literature, as outlined in Section 2, the presence of policies supporting renewable energy development might have limited explanatory power. The actual effect of regulation that is of interest in this context is the duration of the support policy. Utilizing the IEA report on "Renewable energy market and policy trends" and taking only the incentive tariffs, obligations and tradable certificates as the main policy instruments promoting renewable energies into consideration the duration of policies is controlled for as follows:

(4)

$$
\begin{aligned}
& \text { Policy }_{i, t, 5}=1 \text { if Policy implemented for }>5 \text { years and }<10 \text { years } \\
& \text { Policy }_{i, t, 10}=1 \text { if Policy implemented for }>10 \text { years and }<15 \text { years } \\
& \text { Policy }_{i, t, 15}=1 \text { if Policy implemented for }>15 \text { years }
\end{aligned}
$$

Most countries started implementing renewable energy policies in the 1990s. The hypothesis tested, using this set of dummies, is that early introduction of renewable energy regulation will result in better export performance.

\subsection{The role of barriers to trade and regulation in importing countries}

Considering the limited SETC export flows from OECD countries to developing countries it is also of interest to explain the differences in importing these technologies. Therefore, the second hypothesis of this analysis is that receiving countries with a regulatory framework 
supporting renewable energies and with low trade barriers will have greater clean technology imports than countries without supportive frameworks and with higher trade barriers. We include control variables representing environmental regulation and renewable energy supportiveness in importing countries as well as applied import tariffs as these are elements neglected in the literature.

In line with the control for general environmental regulatory strictness in the exporting country, the same index, based on energy intensity (IndexEnvReg $\left.{ }_{j t}\right)$, is constructed for the importing countries in the sample. However, the role of environmental regulation in this context is ambiguous from the theoretical perspective. One effect of enacting environmental regulation may be the induction of demand for a specific clean technology. This could cause additional imports because foreign producers may provide either better or cheaper technology. However, in line with the Porter hypothesis, more stringent environmental regulation may not necessarily increase, and might even reduce technology specific imports if they are provided by the home market.

As outlined, the environmental regulation index is an output oriented measure that is not technology specific. Consequently, proper analysis needs measures that focus on the specific sectors or technology. The control variable comparable to the share of solar electricity in exporting countries is the share of non-hydro renewable net electricity generation out of total net electricity generation (REelect ${ }_{j t}$ ), also obtained from the ElA's International Energy Statistics (2011). Figure 5 suggests that the share of renewable electricity has increased steadily since 1996. Similar to the role of solar electricity share in exporting countries, the variable reflects the results of regulation targeting renewable energy supply expansion and thus the supportiveness of the regulatory system for solar 
energy. The coefficient is expected to be positive as only with strong renewable energy policies technology demand is generated which subsequently can be satisfied through imports. Further, more detailed data for this and for renewable regulation input oriented measures are not available for most importing countries in the sample.

Figure 5: Global non-hydro renewable net electricity generation as share of total net electricity generation 1996-2008.

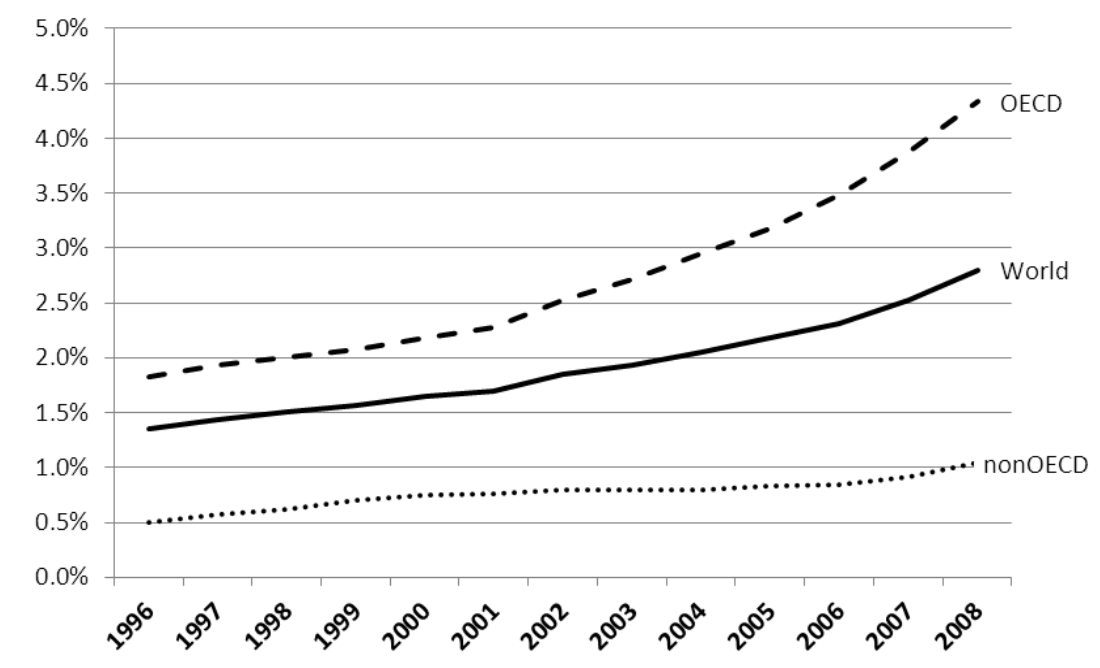

Source: U.S. EIA International Energy Statistics Database (2011).

Studying the determinants of trade, an analysis of trade costs incorporating more than just distance variables should be conducted as tariff and non-tariff barriers may substantially inhibit trade. Consequently, the tariff level (Import Tariff $f_{j i t}$ ) applied to SETC is included as a control variable. By testing the impact of tariff levels this paper also contributes to international climate policy debate: Although international trade is identified as an important instrument for technology transfer (Grossman and Helpman, 1993), as of 2011 WTO negotiations on environmental goods liberalization are deadlocked, while, at the same time, technology transfer remains a central issue in UNFCCC climate talks. As the average tariff, applied to OECD solar technology components imports varies over time, Figure 6 
shows that import tariffs applied to SETC imports from OECD countries by non-OECD countries are substantially higher than tariffs applied by OECD countries. The general tendency however underlines that while exports of OECD countries increased significantly, the mean tariff applied by the sample's importing countries decreased substantially. The coefficient sign expected is negative as bilateral trade flows are higher when tariff levels are low as exporters face reduced trade costs. Data on the effective ad valorem tariff applied by the importing country $j$ to solar technology component imports from $i$ in percent of the import value in $t$ is obtained from the UNCTAD TRAINS database (2010). In order to identify the tariffs applied to the specific solar technology component product group the HS coding system was utilized again as outlined in section 4.1.

Figure 6: Development of OECD solar energy exports and respective mean tariff applied by importing countries.

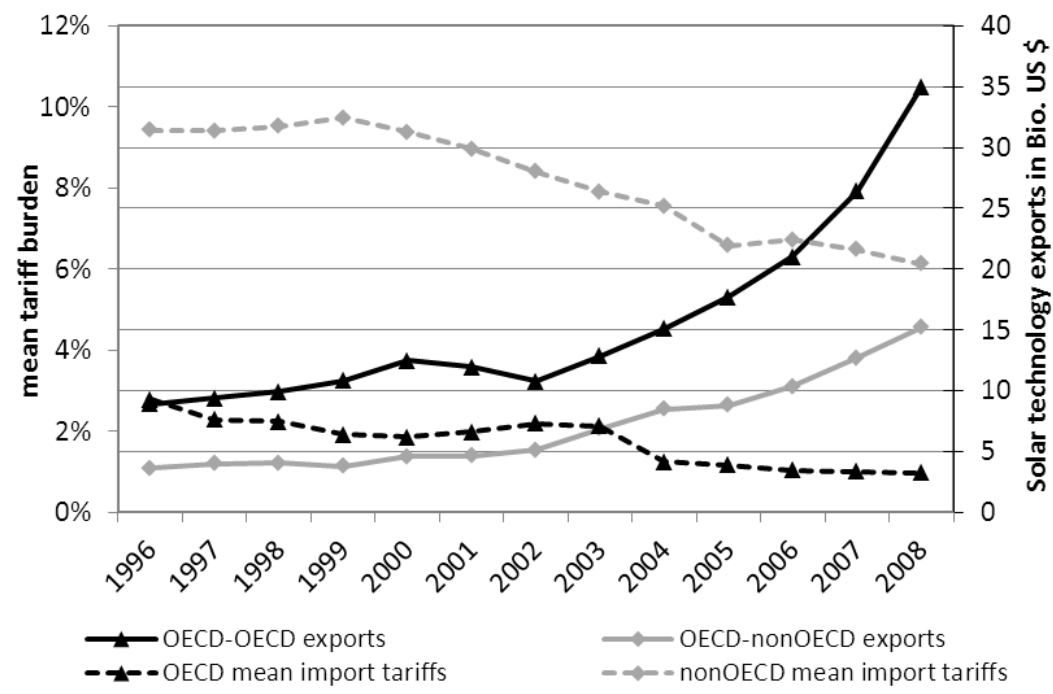

Source: own calculation based on UNCTAD TRAINS database (2010) 


\section{Results}

The study estimates several specifications to determine the impact of environmental and renewable energy policy on SETC trade. Table 2 presents estimates of the impact of environmental regulation and renewable energy policies on trade. The coefficients are estimated using the random effects Poisson pseudo maximum likelihood estimator. All estimated models include time dummies as well as exporting and importing country dummies. The standard errors, in parentheses, are bootstrapped. ${ }^{4}$

Model 1 presents the results for the baseline gravity model showing the expected sign and significance levels. The effects are in line with trade theory and robust across different model specification in columns 2 to 7 . The larger the importing country's income the greater are the SETC exports from OECD countries. The negative sign of the population size in importing countries $j$ is in line with other empirical studies, indicating that importing SETC is positively related rather to the level of income per capita than to the number of consumers as such. Distance and language between trading partners also play and important role where increased distances reduce while common languages significantly increase export flows. Exporting country income does not have a significant impact on solar energy technology exports. This may be explained by the fact that this paper focuses only on exports from high income OECD countries and that, subsequently, other factors characterize country differences and explain higher exports. Therefore, the impact of adding control variables of environmental regulation and renewable energy supportiveness in exporting and importing countries is presented in the following columns.

\footnotetext{
${ }^{4}$ Santos Silva and Tenreyo (2006) suggest using the robust covariance matrix estimator, but the robust estimator of standard errors is not available for fixed effect Poisson estimation (Magee 2008)
} 
Models 2 to 5 present the results of the gravity model accounting for both environmental and renewable energy regulation. In models 2 and 3, output and input oriented measures for environmental regulation, both technology specific and general, are estimated jointly as there is no correlation between these in one period (Appendix 5). However, the duration of input oriented policy instrument measures, such as incentive tariffs and renewable energy obligations schemes, could positively affect the share of renewable electricity generation. Consequently, models 4 and 5 estimate the duration of input oriented measures of renewable energy supportiveness separately from output oriented measures of renewable energy and environmental regulation. Model 3 and 5 extend the specification of model 2 and 4 to control for effects of environmental and renewable energy regulation as well as import tariffs in importing countries.

The results for models 2 and 3 support the weak version of the Porter hypothesis as these show that countries with a stronger regulatory system favoring renewable energy have an SETC export advantage versus countries with week or non-existent policies. Countries spending more on solar energy technology research export more of the respective technology goods. The R\&D budget for solar energy, used as a proxy for policy stringency, has a strong positive and significant effect showing that a one percent increase in the R\&D budget increases solar energy technology exports by 6 percent. The estimated coefficient of the share of solar electricity generation (SolarElect ${ }_{i t}$ ), measuring the success of the regulatory system to support solar energy, shows a positive, although weak, impact on solar energy technology exports. However, the broader output oriented environmental regulation index (IndexEnvReg ${ }_{i t}$ ) is not statistically significant, regardless of model specification. Models 2 and 3 include incentive tariffs, obligations and tradable certificates, which are the major renewable energy support schemes in OECD countries. The coefficients on the policy 
dummies are not statistically significant; suggesting that the mere existence of renewable energy support policies is not relevant when OECD countries to the world exports are considered and the regulatory framework in importing countries is not respected (Model 2).

Table 2: Gravity model estimates of environmental and renewable energy policy effects

\begin{tabular}{|c|c|c|c|c|c|c|c|}
\hline \multicolumn{8}{|c|}{ Poisson Pseudo Maximum Likelihood } \\
\hline & \multicolumn{5}{|c|}{ OECD exports to World } & \multicolumn{2}{|c|}{$\begin{array}{c}\text { OECD exports to } \\
\text { nonOECD }\end{array}$} \\
\hline & Model 1 & Model 2 & Model 3 & Model 4 & Model 5 & Model 6 & Model 7 \\
\hline $\mathrm{GDP}_{\mathrm{i}}$ & -0.97 & $-1.64^{\star \star}$ & $-1.47^{\star \star}$ & -0.75 & -1.06 & $-3.26 \star \star$ & -0.85 \\
\hline $\mathrm{POP}_{\mathrm{i}}$ & $-5.75^{\star \star \star}$ & $-2.78^{\star}$ & $-3.89^{\star}$ & $-7.03^{\star \star \star}$ & $-6.97^{\star \star *}$ & 0.95 & -3.22 \\
\hline $\mathrm{GDP}_{\mathrm{j}}$ & $1.09^{\star \star \star}$ & $1.08^{\star \star \star}$ & $1.06^{\star \star \star}$ & $1.16^{\star \star \star}$ & $1.07^{\star \star \star}$ & $1.95^{\star \star \star}$ & $2.00^{\star \star \star}$ \\
\hline $\mathrm{POP}_{\mathrm{j}}$ & $-3.01^{*}$ & $-2.94^{\star *}$ & -1.59 & $-2.79^{\star}$ & -1.37 & -1.87 & -1.78 \\
\hline distance $_{i j}$ & $-1.31^{\star \star \star}$ & $-1.26^{\star \star \star}$ & $-1.26^{\star \star \star}$ & $-1.31^{\star \star \star}$ & $-1.30 * \star \star$ & $-1.59^{\star \star \star}$ & $-1.65^{\star \star \star}$ \\
\hline language $_{\mathrm{ij}}$ & $1.31^{\star \star *}$ & $1.32^{\star \star \star}$ & $1.27^{\star \star \star}$ & $1.31^{\star \star \star}$ & $1.27^{\star \star \star}$ & $1.52^{\star \star \star}$ & $1.50^{\star \star \star}$ \\
\hline IndexEnvReg ${ }_{i t}$ & & -0.07 & -0.07 & & & -0.20 & \\
\hline SolarElect $t_{i t}$ & & $0.79^{* *}$ & 0.71 & & & 0.42 & \\
\hline RDsolar $_{\text {it }}$ & & $0.07^{* \star *}$ & $0.06^{* \star *}$ & & & $0.13^{\star * \star}$ & \\
\hline incentive tariffs $s_{\text {it }}$ & & -0.01 & -0.02 & & & $0.35^{\star \star \star}$ & \\
\hline obligations $_{\text {it }}$ & & -0.09 & -0.10 & & & -0.06 & \\
\hline tradeable certificates & & 0.03 & -0.00 & & & -0.00 & \\
\hline incentive tariffs $_{\mathrm{it}}>5$ & & & & 0.05 & 0.03 & & $0.22^{\star \star}$ \\
\hline incentive tariffs $_{i t}>10$ & & & & $0.20^{* *}$ & $0.16^{\star *}$ & & $0.40^{* *}$ \\
\hline incentive tariffs $_{\mathrm{it}}>15$ & & & & $0.27^{\star}$ & 0.20 & & $0.56^{\star \star \star}$ \\
\hline obligations $_{\text {it }}>5$ & & & & -0.04 & -0.01 & & $-0.12^{\star \star \star}$ \\
\hline obligations $_{\text {it }}>10$ & & & & $0.15^{\star *}$ & $0.18^{*}$ & & 0.14 \\
\hline obligations $_{i t}>15$ & & & & 0.16 & 0.19 & & 0.27 \\
\hline certificates $_{i t}>5$ & & & & -0.06 & -0.04 & & $-0.18^{\star \star \star}$ \\
\hline certificates $_{i t}>10$ & & & & $-0.24^{\star *}$ & $-0.25^{\star \star}$ & & -0.16 \\
\hline Import Tariff jit & & & -1.13 & & -1.32 & $-1.70^{*}$ & $-1.99 \star \star$ \\
\hline IndexEnvReg jt & & & $-0.58^{\star \star \star}$ & & $-0.65^{\star \star \star}$ & $-0.43^{*}$ & -0.43 \\
\hline REelct $_{j t}$ & & & $0.22^{\star}$ & & $0.20^{\star \star \star}$ & $0.31^{*}$ & $0.29^{\star *}$ \\
\hline constant & $182.98^{\star \star \star}$ & $143.45^{\star \star \star *}$ & $137.82^{\star \star \star}$ & $195.70^{\star \star \star}$ & $182.45^{\star \star \star *}$ & $83.03^{\star}$ & $89.73^{\star \star}$ \\
\hline /Inalpha & $0.45^{\star \star \star}$ & $0.41^{\star \star \star}$ & $0.36^{\star \star \star}$ & $0.45^{\star \star \star}$ & $0.40^{\star \star \star}$ & $0.48^{\star \star \star}$ & $0.52^{\star \star \star}$ \\
\hline Year fixed effects & yes & yes & yes & yes & yes & yes & yes \\
\hline $\begin{array}{l}\text { Exporting. country } \\
\text { fixed effects }\end{array}$ & yes & yes & yes & yes & yes & yes & yes \\
\hline $\begin{array}{l}\text { Importing. country } \\
\text { fixed effects }\end{array}$ & yes & yes & yes & yes & yes & yes & yes \\
\hline $\mathrm{N}$ & 23646 & 20888 & 18285 & 23646 & 20730 & 14104 & 15996 \\
\hline
\end{tabular}


The effect of policy duration on SETC exports is shown by models 4 and 5 . The results are consistent with the lead markets hypothesis as countries that implemented renewable energy support schemes earlier than others export more SETCs. The coefficient on the variable incentive tariffs $s_{i t}>10$ of 0.20 indicates that export flows are estimated to increase by $22 \%\left(e^{0.20}=1.22\right)$ if the incentive tariff policy has been in place for more than ten years. The duration of renewable energy obligations policy has a similar effect. Export flows are estimated to increase by $16 \%\left(e^{0.15}=1.16\right)$ if obligations have been in place for more than 10 years. However, policy duration of more than 15 years for both obligations and incentive tariffs has no effect on STEC exports. This can be explained by the fact that later in the time period analyzed support policies have been adopted by all OECD countries, reducing the market leader effect. The negative effect of the variable certificates $s_{i t}>10$ can be explained by the fact that most OECD countries introduced green certificates late in 2001 and 2002 to supplement other policies such as incentive tariffs and obligations. Only one country, the Netherlands, had a policy in place prior to the start of the time period under study, 1999 to 2007.

Models 3 and 5 estimate the impact of the regulatory framework in importing countries on SETC exports from OECD countries. The results indicate that the regulatory environment in importing countries is an important determinant for SETC exports from OECD countries. More importantly the analysis supports the hypothesis that receiving countries with a regulatory environment supporting renewable energies have greater clean technology imports than countries without supportive frameworks. The broad output oriented measure of environmental regulation (IndexEnvReg $g_{j t}$ ) has a negative significant impact on export flows, lending some support to the strong Porter hypothesis as more stringent environmental regulation in general does not increase imports. Yet, more 
importantly, the coefficient of the share of renewable energy electricity in total electricity generation $\left(\right.$ REelct $\left._{j t}\right)$, measuring the supportiveness of the regulatory system for renewable energies in importing countries, is positive and statistically significant. A one percent increase in REelct ${ }_{j t}$ in the importing country increases solar energy technologies exports from OECD countries by $20 \%$. The effect of trade barriers (Import Tariff $f_{j i t}$ ) on solar energy technology exports is not statistically significant when OECD exports to all importing countries in the sample are analyzed, as in models 2 through 5. Yet, global trade with these energy technology goods is dominated by OECD countries (Appendix 1), which apply very low tariffs compared to non-OECD countries.

As trade between developed and developing countries remains limited, models 6 and 7 present results for exports from OECD countries to non-OECD countries only in order to identify reasons for limited SETC export flows to the developing counties. Both models show robust results for variables estimated in previous model specifications, further strengthening the weak version of the porter hypothesis as well as the lead market hypothesis. Most importantly, however, the second hypothesis that countries with low trade barriers have greater SETC imports than countries with higher trade barriers is supported. The respective coefficient is negative and significant, indicating that a one percent decrease in effectively applied import tariffs (Import Tariff $f_{\text {jit }}$ ) on SETCs in receiving countries $j$, increases export from $i$ by 170 percent (model 6) to 200 percent (model 7). Consequently, the limited exports flows of OECD countries to non-OECD countries are explained by higher import tariffs in importing non-OECD countries. 


\section{Conclusion}

Solar energy is seen as a large potential energy source in the context of combating climate change. Studies analyzing the market development and determinants of the global market of renewable energy technology in general, and solar energy technologies in particular, usually focus on added capacity and investments. The role of the international trade system in this context is often neglected.

By studying the export flows of solar energy technology components (SETC) from OECD countries to the world, this paper provides a unique overview on the structure and development of a dynamic global market. Using a unique data set to unveil a strong growing market dominated by trade between OECD countries, especially the European nations. The paper adds to the current literature and policy debate by analyzing SETC export flows in detail and by estimating an empirical gravity model to identify the main drivers of trade in this technology. The estimation method applied adequately takes both heteroscedasticity and zero trade flows into account.

Strong evidence supporting the Porter hypothesis is found, outlining that environmental regulation and a policy framework supportive of renewable energies are determinants of a strong export performance as countries more strongly committed to renewable energies export more SETCs than countries with weak or non-existent policies. The results also support the lead market hypothesis as countries that introduced renewable energy regulation earlier have become the largest exporters of SETC.

Furthermore, the study shows that a strong renewable energy supporting policy framework in importing countries is also an important element for explaining trade flows. Additionally, the analysis reveals that limited trade with SETCS, particularly between OECD 
and non-OECD countries, can be explained by high import tariffs in non-OECD countries as countries with low tariff barriers import more technology components.

Therefore, although the question to what extent trade with energy technologies is an instrument for technology transfer remains for further research, the results of this study are interesting from a policy perspective as well. The results show that the approach toward sustainable development, set by the European Union's Lisbon strategy and by the OECD, is justified as environmental policies foster export in clean energy technologies. Supporting the argument that low tariffs on solar energy technology components promote technology access, the results of the study suggest that the liberalization of environmental goods within the WTO framework is still relevant and should be continued in order to foster technology access as called for in global climate negotiations. The transfer of best practice policies, such as feed-in tariffs, to create a regulatory environment supportive of renewable energies can be an instrument to further expand the market. 


\section{Appendix}

Appendix 1: Top 15 global exporters of solar energy technology components in 2008 and respective export specialization and comparative advantage indices.

\begin{tabular}{|c|c|c|c|c|c|c|c|c|c|}
\hline & \multicolumn{3}{|c|}{ Country Share of Global Export* } & \multicolumn{3}{|c|}{ Export Specialization ${ }^{* 1}$} & \multicolumn{3}{|c|}{ Comparative Advantage $*^{1}$} \\
\hline & 1997 & 2003 & 2008 & 1997 & 2003 & 2008 & 1997 & 2003 & 2008 \\
\hline China & $6.4 \%$ & $13.6 \%$ & $28.5 \%$ & 45 & 69 & 97 & 70 & 23 & 83 \\
\hline Germany & $14.1 \%$ & $13.2 \%$ & $16.4 \%$ & 21 & 12 & 39 & 17 & -9 & -9 \\
\hline Japan & $15.1 \%$ & $17.5 \%$ & $9.9 \%$ & 47 & 87 & 52 & 42 & 50 & 82 \\
\hline United States & $15.2 \%$ & $9.2 \%$ & $6.3 \%$ & 5 & -10 & -34 & -38 & -13 & -13 \\
\hline Italy & $4.7 \%$ & $3.8 \%$ & $3.2 \%$ & -12 & -21 & -25 & 14 & 13 & -22 \\
\hline France & $5.7 \%$ & $4.2 \%$ & $3.0 \%$ & -10 & -29 & -39 & 0 & 12 & 5 \\
\hline Korea, Rep. & $2.3 \%$ & $2.2 \%$ & $2.9 \%$ & -29 & -30 & -11 & -31 & -90 & -43 \\
\hline United Kingdom & $6.4 \%$ & $4.5 \%$ & $2.8 \%$ & 3 & -7 & -21 & -1 & 36 & 44 \\
\hline Netherlands & $4.2 \%$ & $3.5 \%$ & $2.3 \%$ & 1 & -16 & -60 & -34 & -59 & -35 \\
\hline Sweden & $3.0 \%$ & $2.0 \%$ & $2.1 \%$ & 51 & 24 & 41 & 26 & 26 & 31 \\
\hline Austria & $1.6 \%$ & $1.3 \%$ & $2.1 \%$ & 25 & -5 & 46 & 30 & 5 & 45 \\
\hline Mexico & $4.9 \%$ & $4.2 \%$ & $1.9 \%$ & 69 & 50 & -15 & 39 & 2 & -24 \\
\hline Belgium & $0.0 \%$ & $1.4 \%$ & $1.8 \%$ & . & -104 & -71 & . & -31 & -26 \\
\hline Czech Republic & $0.0 \%$ & $0.5 \%$ & $1.6 \%$ & . & -34 & 36 & . & -36 & -5 \\
\hline Finland & $2.9 \%$ & $1.9 \%$ & $1.5 \%$ & 117 & 86 & 71 & 88 & 65 & 92 \\
\hline Sum: & $86.5 \%$ & $83.0 \%$ & $86.3 \%$ & & & & & & \\
\hline Sum OECD & $83.6 \%$ & $73.2 \%$ & $61.0 \%$ & & & & & & \\
\hline
\end{tabular}

Source: Calculations by the author on basis of UNCTAD Comtrade Data

* only for solar PV and solar thermal energy technology

1 Compared to Industrial goods WTO definition

Explanation:

Indices based on

Export specialization Index:

RXA > 0: export specialization, as countries market share of global technology export larger than average market share of these technologies in global trade, non-additive and without weighing for size of product groups

Comparative advantage Index:

RCA > 0: RCA = RXA-RMA comparative advantage, non-additive and without weighing for the size of product groups 
Appendix 2: Nomenclature of solar energy technology components, HS 1996

HS Code Explanation

Solar Thermal

$841911 \quad$ Instantaneous gas water heaters.

841919 Other instantaneous or storage water heaters, non-electric.

840219 Steam or other vapor generating boilers [Other vapor generating boilers, including hybrid boilers].

841950 Heat exchange units [Heat-exchange units for solar thermal or geothermal applications].

900290 Concentrator systems to intensify solar power in solar energy systems, other optical elements of any material mounted

Solar Photovoltaic

$850440 \quad$ Static converters [Inverters (for converting DC power to AC power)] - change solar energy into electricity.

850720 Other lead-acid accumulators [solar batteries], i.e batteries for energy storage in off-grid photovoltaic systems.

854140 Photosensitive semiconductor devices, including photovoltaic cells whether or not assembled in modules or made up into panels; light emitting diodes.

* Static converters (850440) and Photosensitive semiconductor devices (854140) account for approximately $60 \%$ of OECD exports in this product group in 2008.

Nomenclature based on Steenblik (2005b, 2006b) for HS 1996 and Wind (2008) for HS 2007 
Appendix 3: Definition of variables and data sources

\begin{tabular}{lll}
\hline \hline Variable & Definition & Source \\
\hline DEPENDENT VARIABLE & \\
\hline Solar_EXP & \\
& bilateral export flows in solar energy technologies & UNCTAD \\
& (at constant 2000 $\$ P P P)$ & COMTRADE \\
& & $(2010)$
\end{tabular}

INDEPENDENT VARIABLES

Mass

GDP it and jt

natural logarithm of GDP PPP

WDI (2011)

(at constant 2005 international \$)

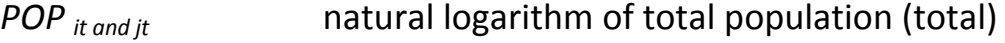

WDI (2011)

Geography

distance $_{i j}$

natural logarithm of bilateral geographic simple distance

CEPII (2010)

(most populated cities, km)

language $_{i j}$

common language in i and $\mathrm{j}$ (dummy variable)

CEPII (2010)

\section{Environmental regulation and renewable energy supportivness}

Energylnt it and jt energy intensity as TPEC in BTU per Dollar of GDP in 2005

$\operatorname{EIA~(2011)~}$

U.S. Dollars

data is used to construct IndexEnvReg ${ }_{i t}$ and $j t$

SolarElect $_{\text {it }}$

natural logarithm of solar electricity generation share

$\operatorname{EIA~(2011)~}$

(solar, tide and wave net electricity generation in billion

$\mathrm{KWh}$ from total net electricity net generation in billion

KWh)

ReElect $_{j t}$

natural logarithm of renewable electricity generation

share (non-hydro renewable energy net electricity

WDI (2010) generation in Bio. KWh from total net electricity net generation in Bio. KWh)

RDsolar $_{\text {it }}$

natural logarithm of public research and development

IEA (2010) budget for solar energy technologies in Mio. U.S. \$

(constant 2005 U.S. \$, PPP)

incentive tariffs it Existence of Incentive Tariff policies (dummy)

IEA (2004)

obligations it

Existence of Obligations (dummy)

IEA (2004)

certificates ${ }_{\text {it }}$

Existence of Tradable Green Certificates (dummy)

IEA (2004)

Import Tariff jit

Effectively applied tariff to solar energy technology

UNCTAD-

imports in $\mathrm{j}$ from $\mathrm{i}$ at $\mathrm{t}$ in \% of import value

TRAINS (2010) 
Appendix 4: Summary Statistics 1999 - 2007

\begin{tabular}{lccccc}
\hline \hline Variable & Obs. & Mean & Std. Dev. & Min & Max \\
\hline SolarEXP $_{\text {ijt }}$ & 24948 & 8301.823 & 46922.140 & 0 & 1679667 \\
GDP $_{\text {it }}$ & 24948 & 27.120 & 1.184 & 25.442 & 30.196 \\
POP $_{\text {it }}$ & 24948 & 16.813 & 1.169 & 15.139 & 19.524 \\
GDP $_{\text {jt }}$ & 24772 & 25.083 & 1.691 & 22.115 & 30.196 \\
POP $_{\text {jt }}$ & 24948 & 16.338 & 1.465 & 12.534 & 21.000 \\
distance $_{\text {ij }}$ & 24948 & 8.498 & 0.887 & 4.105 & 9.885 \\
language $_{\text {ij }}$ & 24948 & 0.089 & 0.285 & 0 & 1 \\
IndexEnvReg $_{\text {it }}$ & 23814 & 0.524 & 0.288 & 0.048 & 1 \\
SolarElect $_{\text {it }}$ & 24948 & 0.023 & 0.047 & 0 & 0.400 \\
RDsolar $_{\text {it }}$ & 21672 & 2.292 & 1.388 & 0 & 5.175 \\
incentive tariffs $_{\text {it }}$ & 24948 & 0.818 & 0.386 & 0 & 1 \\
obligations $_{\text {it }}$ & 24948 & 0.803 & 0.398 & 0 & 1 \\
tradeable certificates $_{\text {it }}$ & 24948 & 0.404 & 0.491 & 0 & 1 \\
Import Tariff $_{\text {jit }}$ & 24435 & 0.062 & 0.069 & 0 & 0.936 \\
IndexEnvReg $_{\text {jt }}$ & 22374 & 0.438 & 0.251 & 0.008 & 0.869 \\
REelct $_{\text {jt }}$ & 22572 & 2.809 & 1.506 & 0 & 4.615 \\
incentive tariffs $_{\text {it }}>5$ & 24948 & 0.702 & 0.457 & 0 & 1 \\
incentive tariff $_{\text {itt }}>10$ & 24948 & 0.460 & 0.498 & 0 & 1 \\
incentive tariffs $_{\text {itt }}>15$ & 24948 & 0.227 & 0.419 & 0 & 1 \\
obligations $_{\text {it }}>5$ & 24948 & 0.576 & 0.494 & 0 & 1 \\
obligations $_{\text {it }}>10$ & 24948 & 0.202 & 0.402 & 0 & 1 \\
obligations $_{\text {it }}>15$ & 24948 & 0.025 & 0.157 & 0 & 1 \\
certificates $_{\text {it }}>5$ & 24948 & 0.172 & 0.377 & 0 & 1 \\
certificates $_{\text {it }}>10$ & 24948 & 0.010 & 0.100 & 0 & 1 \\
\hline \hline & & & & &
\end{tabular}


Appendix 5: Correlation matrix 1999 - 2007

\begin{tabular}{|c|c|c|c|c|c|c|}
\hline & SolarEXP $P_{i j t}$ & $\mathrm{GDP}_{\text {it }}$ & $\mathrm{POP}_{\text {it }}$ & $\mathrm{GDP}_{\mathrm{jt}}$ & $\mathrm{POP}_{\mathrm{jt}}$ & distance $_{i j}$ \\
\hline SolarEXP $_{\mathrm{ijt}}$ & 1 & & & & & \\
\hline $\mathrm{GDP}_{\text {it }}$ & 0.171 & 1 & & & & \\
\hline $\mathrm{POP}_{\text {it }}$ & 0.164 & 0.983 & 1 & & & \\
\hline $\mathrm{GDP}_{\mathrm{jt}}$ & 0.276 & -0.001 & -0.005 & 1 & & \\
\hline $\mathrm{POP}_{\mathrm{jt}}$ & 0.169 & -0.005 & -0.006 & 0.706 & 1 & \\
\hline distance $_{\mathrm{ij}}$ & -0.173 & 0.174 & 0.175 & -0.153 & 0.091 & 1 \\
\hline language $_{i j}$ & 0.053 & 0.097 & 0.075 & -0.021 & 0.017 & 0.043 \\
\hline IndexEnvReg ${ }_{i t}$ & -0.007 & -0.147 & -0.181 & 0.001 & 0.001 & -0.212 \\
\hline SolarElect $_{\text {it }}$ & 0.183 & 0.388 & 0.377 & 0.018 & 0.004 & 0.031 \\
\hline RDsolar $_{\text {it }}$ & 0.151 & 0.844 & 0.820 & -0.004 & -0.005 & 0.124 \\
\hline incentive tariffs $_{i t}$ & -0.037 & -0.067 & -0.073 & 0.010 & 0.004 & -0.221 \\
\hline obligations $_{i t}$ & -0.012 & -0.230 & -0.250 & 0.016 & 0.007 & -0.111 \\
\hline tradeable certificates $_{\text {it }}$ & 0.008 & -0.041 & -0.080 & 0.024 & 0.009 & 0.020 \\
\hline Import Tariff ${ }_{\mathrm{jit}}$ & -0.079 & 0.057 & 0.065 & -0.021 & 0.238 & 0.217 \\
\hline IndexEnvReg ${ }_{j t}$ & 0.012 & 0.000 & 0.000 & 0.004 & 0.061 & -0.220 \\
\hline REelct $_{j t}$ & -0.036 & 0.002 & 0.002 & -0.114 & 0.158 & 0.165 \\
\hline incentive tariff $_{\mathrm{it}}>5$ & -0.007 & -0.001 & -0.017 & 0.016 & 0.005 & -0.202 \\
\hline incentive tariff $s_{i t}>10$ & 0.036 & 0.182 & 0.166 & 0.020 & 0.006 & -0.118 \\
\hline incentive tariffs $_{\text {it }}>15$ & 0.047 & 0.246 & 0.236 & 0.015 & 0.003 & -0.014 \\
\hline obligations $_{i t}>5$ & -0.009 & -0.221 & -0.259 & 0.036 & 0.013 & -0.050 \\
\hline obligations $_{\text {it }}>10$ & -0.032 & -0.252 & -0.288 & 0.030 & 0.011 & -0.033 \\
\hline obligations $_{i t}>15$ & -0.008 & -0.128 & -0.154 & 0.018 & 0.006 & -0.038 \\
\hline certificates $_{i t}>5$ & 0.024 & 0.012 & -0.023 & 0.037 & 0.011 & -0.005 \\
\hline \multirow[t]{2}{*}{ certificates $_{\text {it }}>10$} & 0.006 & -0.001 & -0.018 & 0.011 & 0.003 & -0.024 \\
\hline & language $_{i j}$ & IndexEnvRegit & SolarElect $_{\text {it }}$ & RDsolar $_{i t}$ & $\begin{array}{c}\text { incentive } \\
\text { tariffs }_{\text {it }}\end{array}$ & obligations $_{\text {it }}$ \\
\hline languageij & 1 & & & & & \\
\hline IndexEnvRegi $i_{t}$ & 0.033 & 1 & & & & \\
\hline SolarElect $t_{i t}$ & -0.011 & -0.064 & 1 & & & \\
\hline RDsolar $_{\text {it }}$ & 0.053 & -0.123 & 0.372 & 1 & & \\
\hline incentive tariffs $_{\text {it }}$ & 0.009 & 0.343 & -0.103 & -0.052 & 1 & \\
\hline obligations $_{\text {it }}$ & -0.108 & 0.099 & 0.115 & -0.064 & -0.069 & 1 \\
\hline tradeable certificates $s_{i t}$ & -0.105 & -0.106 & -0.061 & 0.007 & -0.252 & 0.408 \\
\hline Import Tariff $\mathrm{jit}_{\mathrm{j}}$ & 0.017 & -0.024 & -0.006 & 0.056 & -0.035 & -0.036 \\
\hline IndexEnvReg ${ }_{j t}$ & 0.081 & 0.000 & 0.000 & 0.000 & 0.000 & 0.000 \\
\hline REelct $_{j t}$ & 0.013 & 0.000 & 0.000 & 0.002 & 0.000 & 0.000 \\
\hline incentive tariffs $_{\mathrm{it}}>5$ & 0.023 & & & & & \\
\hline incentive tariffs $_{i t}>10$ & 0.034 & & & & & \\
\hline 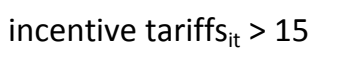 & 0.025 & & & & & \\
\hline obligations $_{i t}>5$ & -0.042 & & & & & \\
\hline obligations $_{i t}>10$ & -0.001 & & & & & \\
\hline obligations $_{\text {it }}>15$ & 0.015 & & & & & \\
\hline certificates $_{i t}>5$ & -0.067 & & & & & \\
\hline certificates $_{i t}>10$ & -0.029 & & & & & \\
\hline
\end{tabular}




\begin{tabular}{|c|c|c|c|c|c|c|}
\hline & $\begin{array}{l}\text { tradeable } \\
\text { certificates }_{\text {it }}\end{array}$ & \multicolumn{2}{|c|}{ Import Tariff $_{\text {jit }}$ IndexEnvReg ${ }_{j t}$} & REelct $_{j t}$ & $\begin{array}{l}\text { incentive } \\
\text { tariffs }_{\text {it }}>5\end{array}$ & $\begin{array}{c}\text { incentive } \\
\text { tariffs }_{\text {it }}>10\end{array}$ \\
\hline tradeable certificates $_{\text {it }}$ & 1 & & & & & \\
\hline Import Tariff jit $_{\text {. }}$ & -0.041 & \multicolumn{2}{|l|}{1} & & & \\
\hline IndexEnvReg ${ }_{j t}$ & 0.000 & -0.001 & \multicolumn{2}{|l|}{1} & & \\
\hline REelct $_{j t}$ & 0.001 & -0.014 & 0.6008 & 1 & & \\
\hline incentive tariffs $s_{\mathrm{it}}>5$ & & -0.036 & 0.000 & 0.000 & \multirow{2}{*}{$\begin{array}{c}1 \\
0.601\end{array}$} & \\
\hline incentive tariffs $_{\text {it }}>10$ & & -0.033 & 0.000 & 0.000 & & 1 \\
\hline incentive tariffs $_{\mathrm{it}}>15$ & & -0.018 & 0.000 & 0.000 & 0.353 & 0.588 \\
\hline obligations $_{i t}>5$ & & -0.071 & 0.000 & 0.001 & 0.066 & 0.136 \\
\hline obligations $_{\text {it }}>10$ & & -0.058 & 0.000 & 0.000 & 0.025 & 0.192 \\
\hline obligations $_{i t}>15$ & & -0.038 & 0.000 & -0.002 & 0.035 & 0.110 \\
\hline certificates $_{\mathrm{it}}>5$ & & -0.038 & 0.000 & -0.002 & -0.113 & -0.017 \\
\hline \multirow[t]{3}{*}{ certificates $_{\mathrm{it}}>10$} & & -0.038 & 0.000 & -0.002 & -0.045 & -0.093 \\
\hline & incentive & \multicolumn{5}{|c|}{ obligations $_{s_{i}}>$ obligations $s_{i t}>$ obligations $s_{i t}>$ certificates $_{i t}>$ certificates $_{s_{i t}}$} \\
\hline & tariffs $_{\text {it }}>15$ & 5 & 10 & 15 & 5 & 10 \\
\hline incentive tariffs $_{\text {it }}>15$ & 1 & & & & & \\
\hline obligations $_{i t}>5$ & 0.051 & 1 & & & & \\
\hline obligations $_{\text {it }}>10$ & 0.087 & 0.432 & 1 & & & \\
\hline obligations $_{\text {it }}>15$ & 0.220 & 0.138 & 0.320 & 1 & & \\
\hline certificates $_{\text {it }}>5$ & -0.087 & 0.391 & 0.338 & 0.097 & 1 & \\
\hline certificates $_{i t}>10$ & -0.055 & 0.087 & 0.201 & -0.016 & 0.222 & 1 \\
\hline
\end{tabular}




\section{Acknowledgements}

The author would like to thank Jan Abrell, Frauke Braun, Claudia Kemfert, Florian Mölders, Petra Zloczysti and Christian von Hirschhausen as well as the participants of the $34^{\text {th }}$ IAEE Conference in Stockholm and the WREC 2011 conference in Linköping for valuable comments on this research. Further gratitude goes to Adam Lederer and Beatrice Pagel for the care with which they reviewed the original manuscript. The author is also grateful to the German Institute of Economic Research (DIW Berlin), especially to Professor Claudia Kemfert, for hosting this research. Support from the Heinrich-Böll-Foundation is gratefully acknowledged. The errors, idiocies and inconsistencies remain my own.

\section{References}

Anderson, J., E., van Wincoop, E., 2003. Gravity with Gravitas: A Solution to the Border Puzzle. American Economic Review 93, 170-192.

Anderson, J.E., 1979. A Theoretical Foundation for the Gravity Equation. American Economic Review 69, 106-116.

Antweiler, W., Copeland, B.R., Taylor, S.M., 2001. Is Free Trade Good for the Environment? American Economic Review 91, 877-908.

Beise, M., 2004. Lead Markets: Country-Specific Drivers of the Global Diffusion of Innovations. Research Policy 33, 997-1018.

Beise, M., Rennings, K., 2005. Lead Markets and Regulation: A Framework for Analyzing the International Diffusion of Environmental Innovations. Ecological Economics 52, 5-17.

Bergstrand, J.H., 1985. The Gravity Equation in International Trade: Some Microeconomic Foundations and Empirical Evidence. Review of Economics and Statistics 67 3, 474-481.

Bergstrand, J.H., 1989. The Generalized Gravity Equation, Monopolistic Competition, and the Factor-Proportions Theory in International Trade. The Review of Economics and Statistics 71, 143-153.

Burger, M., van Oort, F., Linders, G.-J., 2009. On the Specification of the Gravity Model of Trade: Zeros, Excess Zeros and Zero-inflated Estimation. Spatial Economic Analysis 4, $167-$ 190.

Copeland, B.R.T.M.S., 2003. Trade and the Environment: Theory and Evidence. Princton University Press. 
Costantini, V., Crespi, F., 2008. Environmental Regulation and the Export Dynamics of Energy Technologies. Ecological Economics 66, 447-460.

de Vries, F.P., Withagen, C., 2005. Innovation and Environmental Stringency: The Case of Sulfur Dioxide Abatement. Tilburg University, Center for Economic Research Discussion Paper 2005-18.

Dechezleprêtre, A., Glachant, M., Haščič, I., Johnstone, N., Ménière, Y., 2011. Invention and Transfer of Climate Change-Mitigation Technologies: A Global Analysis. Review of Environmental Economics and Policy 5, 109-130.

Egger, P., 2000. A note on the proper econometric specification of the gravity equation. Economics Letters 66, 25-31.

Egger, P., Pfaffermayr, M., 2003. The proper panel econometric specification of the gravity equation: A three-way model with bilateral interaction effects. Empirical Economics 28, 571580 .

EIA, 2011. International Energy Statistics. U.S. Energy Information Administration, Wahsington D.C.

EREC, Greenpeace, 2007. Energy Revolution: A Sustainable World Energy Outlook, Brussels.

Feenstra, R., 2002. Border Effects and the Gravity Equation: Consitent Methods for Estimation. Scottish Journal of Political Economy 49 (2002), 491-506.

Feenstra, R.C., Markusen, J.R., Rose, A.K., 2001. Using the Gravity Equation to Differentiate among Alternative Theories of Trade. Canadian Journal of Economics 34 2, 430-447.

Frankel, J.A., 1997. Regional Trading Blocs in the World Economic System. Institute for International Economics, Washington D.C.

Galeotti, M., Kemfert, C., 2004. Interactions between climate and trade policies, a Survey. Journal of World Trade 38, 701-724.

Grether, J.-M., de Melo, J., 2003. Globalization and Dirty Industires: Do Pollution Havens Matter?, , NBER Working Papers, Cambridge, MA.

Grossman, G., Helpman, E., 1990. Comparative Advantage and Lon-run Growth. Amercian Economic Review 80, 796-815.

Grossman, G.M., Helpman, E., 1993. Innovation and Growth in the Global Economy. MIT Press, Cambridge.

Hamwey, R., 2005. Environmental Goods: Where Do the Dynamic Trade Opportunities for Developing Countries Lie?, International Trade. EconWPA.

Harris, M.N., Konya, L., Matyas, L., 2002. Modelling the Impact of Environmental Regulations on Bilateral Trade Flows: OECD, 1990-1996. World Economy 25, 387-405.

Helpman, E., Melitz, M., Rubinstein, Y., 2008. Estimating Trade Flows: Trading Partners and Trading Volumes. Quarterly Journal of Economics 123, 441-487.

IEA, 2004. Renewable Energy, Market \& Policy Trends in IEA Countries. Organisation for Economic Cooperation and Development, Paris.

IEA, 2009. World Energy Outlook 2009, Paris.

IEA, 2010a. Energy technology research and development database, in: IEA (Ed.), Paris.

IEA, 2010b. World Energy Outlook 2010, Paris. 
Jaffe, A.B., Newell, R., Stavins, R.N., 2002. Environmental Policy and Technological Change. Environmental and Resource Economics 22, 41-70.

Jaffe, A.B., Palmer, K., 1997. Environmental Regulation And Innovation: A Panel Data Study. Review of Economics and Statistics 79, 610-619.

Jaffe, A.B., Stavins, R.N., 1995. Dynamic Incentives of Environmental Regulations: The Effects of Alternative Policy Instruments on Technology Diffusion. Journal of Environmental Economics and Management 29, 43-63.

Johnstone, N., Hascic, I., Popp, D., 2010. Renewable Energy Policies and Technological Innovation: Evidence Based on Patent Counts. Environmental and Resource Economics 45, 133-155.

Jug, J., Mirza, D., 2005. Environmental Regulation in Gravity Equations: Evidence from Europe. World Economics 28, 1591 - 1615.

Krugman, P.R., 1979. Increasing returns, monopolistic competition, and international trade. Journal of International Economics 9, 469-479.

Levinson, A., 2009. Technology, International Trade, and Pollution from US Manufacturing. American Economic Review 99, 2177-2192.

Magee, C.S.P., 2008. New measures on Trade creation and trade diversion. Journal of International Economics 75, 349-362.

Matyas, L., 1998. The Gravity Model: Some Econometric Considerations. The World Economy 21, 397-401.

McCallum, J., 1995. National Borders Matter: Canada-U.S. Regional Trade Patterns. American Economic Review 85, 615-623.

OECD, Eurostat, 1999. The Environmental Goods and Services Industry - Manual for Data Collection and Analysis. OECD, Paris.

Popp, D., 2006. International innovation and diffusion of air pollution control technologies: the effects of NOX and SO2 regulation in the US, Japan, and Germany. Journal of Environmental Economics and Management 51, 46-71.

Porter, M.E., van der Linde, C., 1995. Toward a New Conception of the EnvironmentCompetitiveness Relationship. Journal of Economic Perspectives 9 4, 97-118.

REN21, 2009. Renewables Global Status Report: 2009 Update. Ren 21 Secretariat, Paris.

Ruiz, J., Vilarrubia, J., 2008. The wise use of dummies in gravity models: export potentials in the euromed region. Banco de España Working Papers 0720.

Santos Silva, J.M.C., Tenreyo, S., 2006. The Log of Gravity. The Review of Economics and Statistics 88, 641-658.

Santos Silva, J.M.C., Tenreyo, S., 2010a. Currency unions in prospect and retrospect. Annual Review of Economics 2, 51-74.

Santos Silva, J.M.C., Tenreyo, S., 2010b. On the existence of the maximum likelihood estimates in Poisson regression. Economics Letters 107, 310-312.

Schumacher, D., Siliverstovs, B., 2009. Estimating gravity equations: to log or not to $\log$ ? Empirical Economics 36, 645-669.

Steenblik, R., 2005a. Environmental Goods: A Comparism of the APEC and the OECD list. OECD Trade and Environment Working Paper No. 2005-04. 
Steenblik, R., 2005b. Liberalisation of Trade in Renewable-Energy Products and Associated Goods: Charcoal, Solar Photovoltaic Systems, and Wind Pumps and Turbines. OECD Trade Directorate, OECD Trade and Environment Working Papers: 2005/7.

Steenblik, R., 2006a. Liberalisation of Trade in Renewable Energy and Associated Technologies: Biodiesel, Solar Thermal and Geothermal Energy. OECD Trade Directorate, OECD Trade and Environment Working Papers: 2006/1.

Steenblik, R., 2006b. Liberalisation of Trade in Renewable Energy and Associated Technologies: Biodiesel, Solar Thermal and Geothermal Energy. OECD Trade Directorate, OECD Trade and Environment Working Papers: 2006/1.

Tinbergen, J., 1962. Shaping the World Economy: Suggestions for an International Economic Policy. The Twentieth Century Fund, New York.

UNCTAD, 1995. Environmental Preferable Goods (EPPs) as Trade Opportunity for Developing Countries, Geneva.

UNCTAD, 2003. Environmental Goods: Trade Statistics of Developing Countries, in: Board, T.a.D. (Ed.). UNCTAD, Geneva.

UNCTAD, 2010. World Investment Report 2010 - Investing in a Low Carbon Economy, New York.

UNEP, 2010. Global Trends in Sustainable Energy Investment 2010 Analysis of Trends and Issues in the Financing of Renewable Energy and Energy Efficiency. UNEP, Bloomberg New Energy Finance Paris.

UNFCCC, 2007. Report of the Conference of the Parties on its thirteenth session, held in Bali from 3 to 15 December 2007., Geneva.

UNFCCC, 2009. Report of the Conference of the Parties on its fifteenth session, held in Copenhagen from 7 to 19 December 2009. , Geneva.

van Beers, C., can den Bergh, J.C.J.M., 1997. An Empirical Multi-country Analysis of the Impact of Environmental Regulations on Foreign Trade Flows. Kyklos 50, 29-46.

Vollebergh, H., Kemfert, C., 2005. The Role of Technological Change for a Sustainable Development. Ecological Economics 54, 133-147.

Wang, C., Wei, Y., Liu, X., 2010. Determinants of bilateral Trade Flows in OECD countries: Evidence from Gravity Panel Data Models. The World Economy 33, 894-915.

Wind, I., 2008. HS Codes and the Renewable Energy Sector. ICTSD Programme on Trade and Environment, Geneva.

Yin, H., Powers, N., 2010. Do state renewable portfolio standarts promote in-state renewable generation. Energy Policy 38, 1140-1149.

Young, A., 1991. Learning by Doing an the Dynamic Effects of International Trade. Quaterly Journal of Economics 106, 369-405. 